\title{
Longest recorded trans-Pacific migration of (1) casasuat a whale shark (Rhincodon typus)
}

\author{
Hector M. Guzman ${ }^{\text {* }}$, Catalina G. Gomez ${ }^{1}$, Alex Hearn² and Scott A. Eckert ${ }^{3}$
}

\begin{abstract}
Whale sharks (Rinchodon typus) are found in shallow coastal and deep waters of tropical and warm temperate seas. Population genetic studies indicate high connectivity among populations, and an Indo-Pacific meta-population has been suggested with potential migrations among some ocean basins. Here, we present the satellite track of a transPacific migration of a female whale shark, which we tagged at Coiba Island (Panama), and which travelled over 20,000 km from the Tropical Eastern Pacific (Panama) to the western Indo-Pacific (Mariana Trench) in $841 \mathrm{~d}$, primarily via the North Equatorial Current. This finding illustrates the migratory pathway between two ocean basins and potential passageway to reach the Philippine Sea into the South China Sea.
\end{abstract}

Keywords: Whale sharks, Eastern Pacific, North Pacific current, Mariana trench, Connectivity, Satellite tracking, Panama

\section{Background}

The migratory behaviour of marine species has been the subject of several studies (e.g., Block et al. 2001; Eckert et al. 2002; Eckert 2006; Schick et al. 2013). In many cases, the purpose of undertaking transoceanic migrations or interhemispheric movements by these species seems to be a response to the need for residence in different habitats to optimize growth and foraging opportunities or to breed at discrete geographical locations (Luschi 2013). As indicated by Block et al. (2011), the identification of critical habitats across several jurisdictions is key for spatial planning, informing international policy for resources management at ecosystem level. Consequently, satellite tracking of highly migratory species can provide reliable background information for the identification of potential foraging areas and transoceanic marine corridors (Block et al. 2011), and migratory movements in response to climate change adaptation (Robinson et al. 2009; Poloczanska et al. 2013). Furthermore, population gene flow and connectivity are essential elements for evaluating conservation status of marine species, particularly for migratory species missing well-defined spatial and temporal scale to estimate or model population size.

\footnotetext{
* Correspondence: guzmanh@si.edu

'Smithsonian Tropical Research Institute, PO Box 0843-03092, Panama,

Republic of Panama

Full list of author information is available at the end of the article
}

Among all groups of marine species, seabirds undertake the longest migrations across the oceans, although whales and sea turtles also migrate across vast distances (Eckert 2006; Rosenbaum et al. 2014). However, clearly defined migratory routes have not been identified for many fish species, and for some pelagic species it is unclear why they travel long distances (Luschi 2013). Among sharks in particular, Weng et al. (2005) reported that salmon sharks (Lamna ditropis Hubbs \& Follett 1947) travelled over 18,220 km in $640 \mathrm{~d}$. The white shark (Carcharodon carcharias L. 1758) retains the record for the longest travelled distance of 20,000 km in 9 months (Bonfil et al. 2005), and whale sharks (Rinchodon typus Smith 1828) were reported to travel $13,000 \mathrm{~km}$ in 37 months in the eastern Pacific (Eckert and Stewart 2001) and $7213 \mathrm{~km}$ from the Caribbean to the Atlantic Ocean in 5 months (Hueter et al. 2013). Herein we present the trans-Pacific route of a satellite-tagged $R$. typus from Panama.

\section{Methods}

On 16 September 2011, three female $R$. typus were observed together at Wahoo Rock in the Coiba National Park $\left(07^{\circ} 41.172^{\prime} \mathrm{N}-081^{\circ} 36.548^{\prime} \mathrm{W}\right)$ and tagged with a near real-time tether/towed satellite transmitter model SPOT 253C (Wildlife Computers, Redmond, Washington, USA). The tag model specifies a battery life of $280 \mathrm{~d}$ assuming 250 Argos transmissions per day occurring only 
when the animal is swimming near the surface and the transmitter is exposed. To maximize battery life, transmitters were programed to limit transmissions to a time block from 01:00 to 22:00 h every $2 \mathrm{~d}$ and to slow repetition rate after 10 successive dry transmissions. Time-At-Temperature (TAT) data were programmed and stored in 12 bin-ranges (in degrees Celsius: -40 to $-20,-19.9$ to $-10,-9.9$ to -5 , - 4.9-0, 0.1 to $5,5.1$ to $10,10.1$ to $15,15.1$ to $25,25.1$ to 35 , 35.1 to $45.1,45.2$ to 55 and 55.1 to 60 ). Data were packaged in 6-h intervals starting at 00:00 GMT. Given the width of the bin ranges, the TAT data obtained, were not informative about the potential depth of the shark and were therefore not utilized in our analyses. The float tag was attached to the animal ca. $10 \mathrm{~cm}$ below the first dorsal fin by a $1.5 \mathrm{~m}$ tether made of stainless steel cable and a $3.5 \mathrm{~cm}$ stainless steel dart using a $3.0 \mathrm{~m}$ Manny Puig ${ }^{\mathrm{mm}}$ pole spear.

Doppler-estimated positions were obtained for the sharks through the Argos satellite system and assigned a location quality number based on the location error from 3 ( $<250 \mathrm{~m}$ error) to 0 ( $>1500 \mathrm{~m}$ error) or letter where error estimate could not be calculated (A - 3 messages, B - 2 messages) (Argos CLS 2011).

For the purpose of this manuscript, we used ARCGIS version 10.2 to analyse the track of a single individual with an unusual route: a $7 \mathrm{~m}$ long female (PTT No. 107715, named "Anne" after A. McEnany). This track was compared with a previously published similar route for a $7.1 \mathrm{~m} R$. typus (sex unknown) tagged with a SDRT16 model (Wildlife Computers) in Bahia de Los Angeles, Mexico in September 1995 (see Eckert and Stewart 2001).

\section{Results}

The first transmission occurred $28 \mathrm{~d}$ after tagging, indicating that the shark was close to the surface infrequently. The tag transmitted sporadically from the tagging date to 14 January 2014 for a total of $841 \mathrm{~d}$ (ca. $2.3 \mathrm{y}$ ). Daily sequences of transmission times occurred throughout the day and were not continuous (Fig. 1a), indicating that the tag was attached to the animal during the entire study and not floating with currents (Hearn et al. 2013). Transmission quality varied considerably as expected for marine animals, with most transmissions within location classes A and B (Fig. 1b) (see Tougaard et al. 2008; Costa et al. 2010; Douglas et al. 2012; Hearn et al. 2013 for a review of location class errors used in satellite telemetry).

Anne remained in Panamanian waters for $116 \mathrm{~d}$, transmitting relatively frequently in the eastern Pacific for $226 \mathrm{~d}$ from Panama to Clipperton Island. She travelled at approximately $35 \mathrm{~km}$ from Cocos Island (Costa Rica), $300 \mathrm{~km}$ from the major aggregation site at Darwin Island (Galapagos, Ecuador; Hearn et al. 2013) and $154 \mathrm{~km}$ from Clipperton Island (Fig. 2b-c). Transmissions were interrupted at the end of April 2012, $266 \mathrm{~d}$ after tagging, but transmissions began again $371 \mathrm{~km}$ south of Hawaii after $235 \mathrm{~d}$ of silence. The shark constantly transmitted in Hawaiian waters for ca. 9 d (Fig. 2d) and continued throughout the Marshall Islands for approximately 268 $\mathrm{d}$, passing at $211 \mathrm{~km}$ and $248 \mathrm{~km}$ northeast from Bikar Atoll and Eniwetok Atoll, respectively (Fig. 2e). Transmissions were interrupted again until 6 December 2013, when the shark reached the Mariana Trench $591 \mathrm{~km}$ north of Saipan (Fig. 2f) and transmitted in the area for ca. 112 consecutive days. Anne travelled a record long distance of approximately 20,142 km (or 13,819 km straight-line distance) from Panama to the Marianas Trench (Fig. 2a). Throughout this period, she spent her entire time in temperatures ranging from $15.1-35{ }^{\circ} \mathrm{C}$, indicating that she did not make vertical movements below the thermocline. However, the data collection bin ranges were not narrow enough to establish whether or not the tag was at the surface for the entire track.

Eckert and Stewart (2001) reported a route comparable to that of Anne. Their shark was tracked intermittently for over $300 \mathrm{~d}$, reaching the Karin Seamount ca. $145 \mathrm{~km}$ north of Johnston Atoll (red track in Fig. 2a) and entering the NEC between the Clipperton and Revillagigedo Islands $\left(14^{\circ} \mathrm{N}-117^{\circ} \mathrm{W}\right)$. They provided a map of the location data that illustrates a gap in Argos reported locations between 5 August 1996 and 8 May 1998, but unpublished data show that the transmitter continued to operate and provided 36 uplinks during that gap as the shark moved across the Pacific. Although the uplinks were not long enough for the Argos system to establish a position fix or obtain temperature data, the authors were able to confirm that the shark was moving through this area based on satellite pass-time predictions and the date and time of the uplinks.

\section{Discussion}

The route taken by the shark followed primarily the westward NEC between $10^{\circ} \mathrm{N}$ and $27^{\circ} \mathrm{N}$, entering around Clipperton Island. This track was similar to that of a shark tracked by Eckert and Stewart (2001) from the Gulf of California, Mexico. The NEC is described as "the strongest, exhibits the largest fluctuations, and has the strongest seasonal signal" (Wyrtki 1967), and it weakens during the first half of the year when it is influenced by strong northeast trade winds (see Wyrtki 1974). Anne may have entered the NEC between April and June. This intensive surface flow reaches the western boundary and bifurcates into the Kuroshio and Mindanao currents (Qiu et al. 2015), both within the average latitude $15.5^{\circ} \mathrm{N}$ and longitude $130^{\circ} \mathrm{E}$ off the Philippines Basin (Toole et al. 1990; Kim et al. 2004), about $1900 \mathrm{~km}$ from the last transmission. 

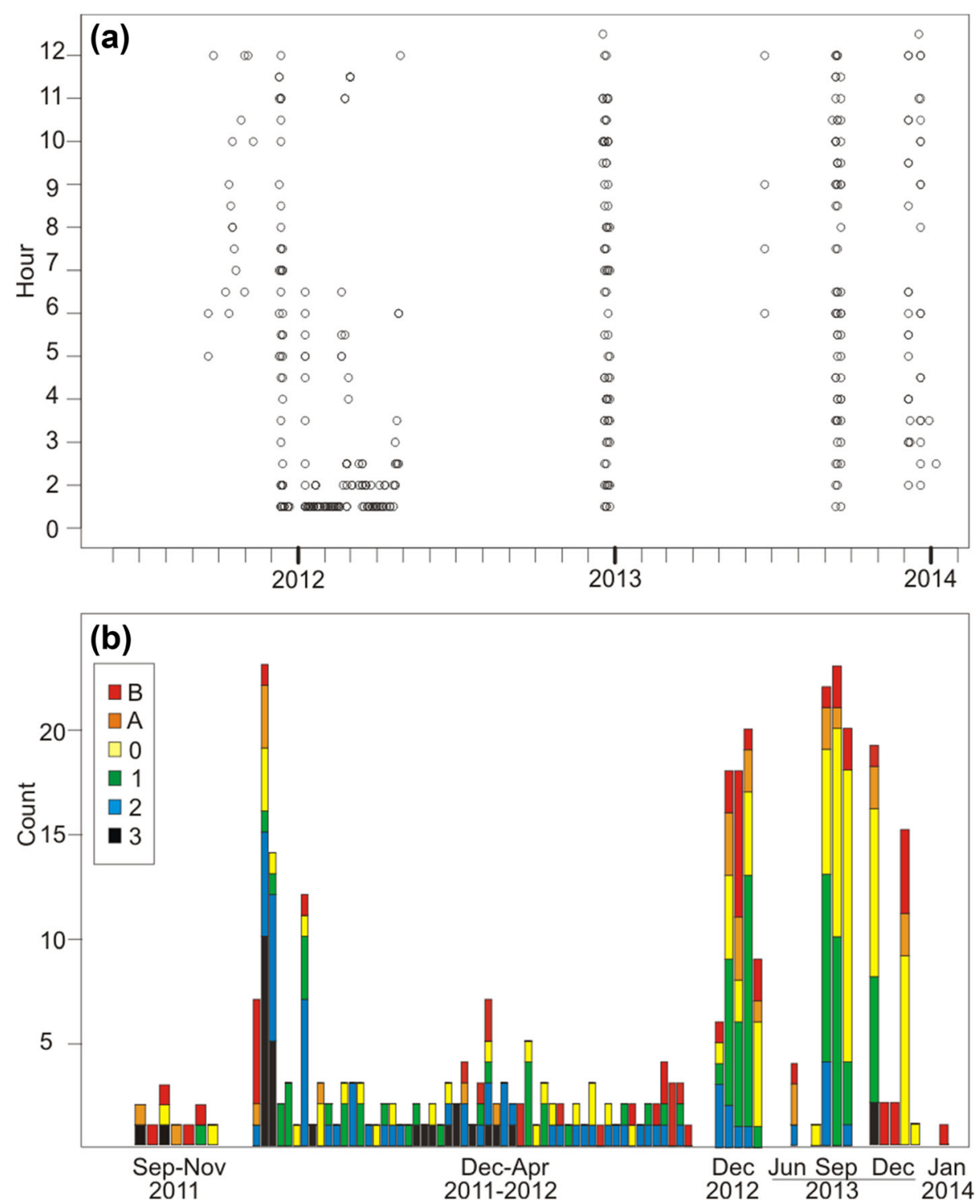

Fig. 1 Daily sequences of transmission time of data in Coordinated Universal Time (a) and daily transmission quality (b) for whale shark No 107715. Transmission quality ranges from 3 to 0 (highest to lowest) and A and B (no perfect positional error estimate)

The longest movement records for $R$. typus varied from $7000 \mathrm{~km}$ in the Caribbean-Atlantic Ocean (Hueter et al. 2013) to $8025 \mathrm{~km}$ in Malaysia (Eckert et al. 2002) to $13,000 \mathrm{~km}$ in northeast Pacific (Eckert and Stewart 2001). This last and longest record was recently questioned by Sequeira et al. (2013) and Hearn et al. (2013) partly because of the lack of surface intervals, and partly because of the unprecedented rate of travel. However, at that time, existing tracking data on whale sharks was almost exclusively composed of tracks of small individuals, and lengthy tracks were rare. Hearn et al. (2016) showed that large females tracked from the Galapagos Islands were able to sustain average movement rates of $67 \mathrm{~km} /$ day. There was also considerable variation between individuals in the frequency of detections. One large female tagged at the Galapagos Islands surfaced off the shelf break of Peru after an interval of 4 months, which represents a movement consistent with that of other female $R$. typus that provided more frequent positions (Hearn et al. 2013, 2016; Ryan et al. 2017) and is related to thermal frontal systems instead of ocean current flow directions (but see Wilson et al. 2006; Sleeman et al. 2010). These results show that lengthy periods without transmissions do not necessarily imply tag shedding. Further, Eckert and Stewart (2001) 

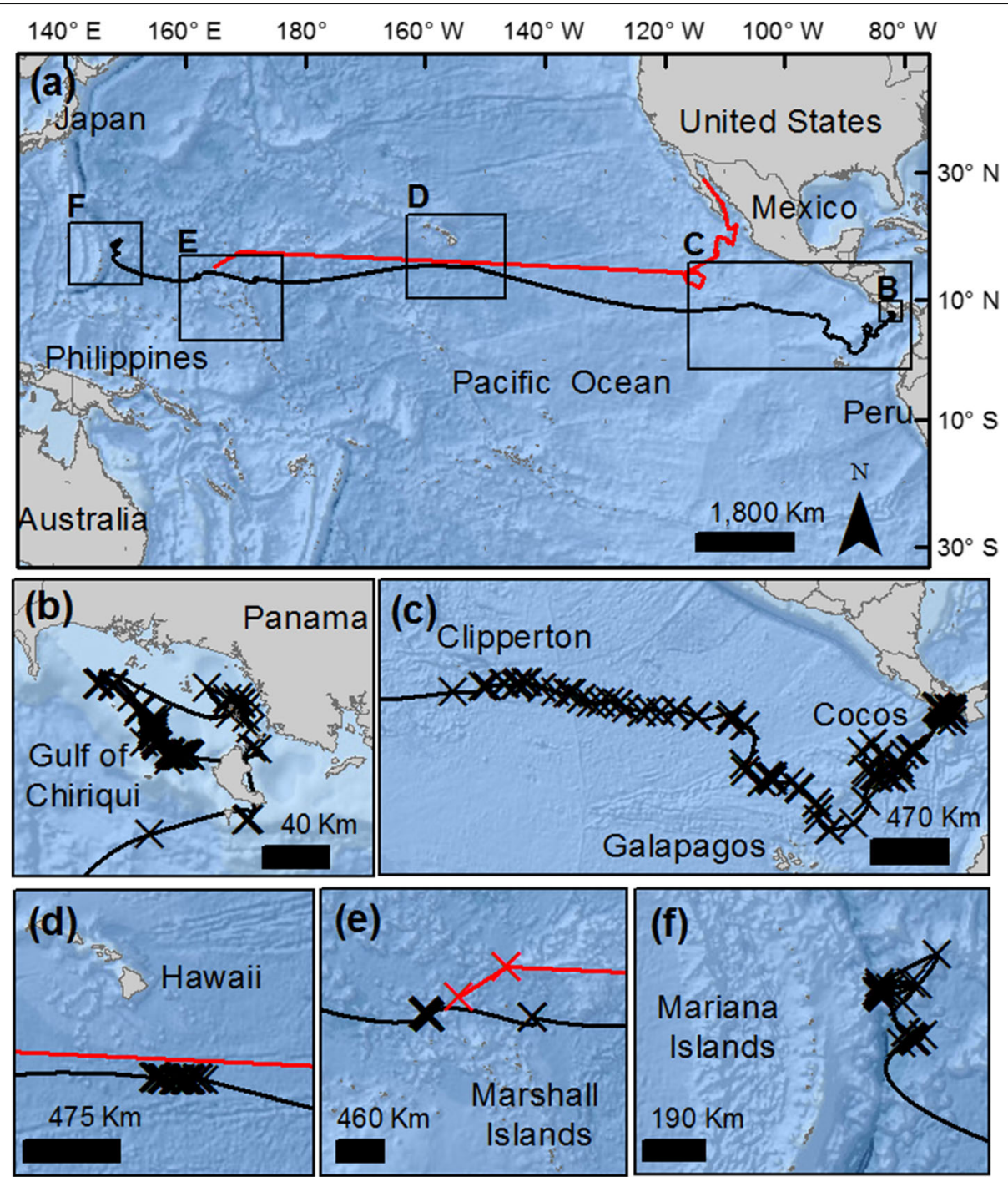

Fig. 2 Rhincodon typus route from Panama to the Mariana Islands (black track) tagged in September 2011 and from Mexico to the Marshall Islands (red track, tagged in September 1995 and published in Eckert and Stewart 2001) (a); and details of tracks for Panama (b); eastern Pacific (c); Hawaii (d); Marshall Islands (e), and Mariana Islands (f)

reported that one shark spent more than $15 \%$ of its time below $10 \mathrm{~m}$ (as deep as $240 \mathrm{~m}$ ), and three others spent more than $5 \%$ of their time below $10 \mathrm{~m}$.

While we recognize that these tracks are unusual given the distance travelled and the intervals between detection periods, we believe the observed routes support a growing body of evidence from both tracking and genetic studies that suggests that $R$. typus is capable of long-distance travel (Eckert and Stewart 2001; Castro et al. 2007; Sequeira et al. 2013; Vignaud et al. 2014). The tracks show a potential passageway via the NEC to reach the Philippine Sea and move into the South China Sea. The results also are consistent with recent genetic studies that suggest a single Indo-Pacific population that is separate from a second Atlantic population (Vignaud et al. 2014).
The last set of transmissions was approximately $1900 \mathrm{~km}$ from the western bifurcation of the NEC. Sequeira et al. (2013) considered it "biologically plausible" for $R$. typus to travel $10,000 \mathrm{~km} / \mathrm{y}$ at an average speed of $30 \mathrm{~km} / \mathrm{d}$, thus connecting South Africa and Ningaloo in $2 \mathrm{y}$. This scenario is similar to the $2.3 \mathrm{y}$ trans-Pacific route described herein and even faster than the $7213 \mathrm{~km}$ in $150 \mathrm{~d}$ described by Hueter et al. (2013). However, testing predictions for a poleward shift in distribution and abundance to avoid higher temperature waters (sensu Sequeira et al. 2014) may require improved current modelling that involves coupling real-time tracks of sharks and remote sensing of environmental variables (e.g., sea surface temperature, chlorophyll concentration, geostrophic 
currents, sea surface height). In addition, a more complete or improved sub-population genetic analysis at discrete regions is needed (sensu Castro et al. 2007; Schmidt et al. 2009; Sequeira et al. 2013, 2014).

\section{Conclusions}

Whale sharks from the Eastern Pacific sub-population can migrate to the Western Indo-Pacific connecting two ocean basins using the North Equatorial Current, suggesting a potential passageway to reach the Philippine Sea into the South China Sea to reach the Indian Ocean. The results also are consistent with recent genetic studies showing potential dispersal for $R$. typus (Castro et al. 2007; Schmidt et al. 2009) and support previous inferred connectivity routes (sensu Sequeira et al. 2013). Block et al. (2011) suggested the creation of "migratory corridors that link the eastern and western Pacific basins for transoceanic migrants". These two tracks for $R$. typus expose the complexity for management of endangered population species crossing multiple jurisdictions while the protection and conservation measures are mostly focused at local level rather than across the Pacific.

\section{Abbreviations \\ ARCGIS: Aeronautical reconnaissance coverage geographic information system; ARGOS: Advanced research and global observation satellite; NEC: North Equatorial Current; PTT: Platform terminal transmitter; SPOT: Smart position and temperature tag}

\section{Acknowledgments}

We are grateful to Kevan Mantell for support during tagging expeditions. We thank anonymous reviewers for comments on the manuscript.

\section{Funding}

The project was partially funded by the International Community Foundation-CANDEO, the Smithsonian Tropical Research Institute, and the Secretaria Nacional de Ciencia y Tecnología e Innovación de Panamá (SENACYT).

\section{Availability of data and materials}

The datasets used and/or analyzed during the current study are not publicly available due to potential further modeling but are available from the corresponding author upon reasonable request.

\section{Authors' contributions}

HMG conceived the study, carried out fieldwork, and provided data with SAE. All authors prepared the manuscript and contributed to the analyses. All authors edited, read, and approved the final manuscript.

\section{Ethics approval and consent to participate}

The procedures considered all applicable international, national, and/or institutional guidelines for the care and use of animals and were in accordance with the ethical standards of the institution or practice at which the studies were conducted. The Animal Care and Use Committee of the Smithsonian Tropical Research Institute approved the tagging procedure.

\section{Competing interests}

The authors declare that they have no competing interests.

\section{Publisher's Note}

Springer Nature remains neutral with regard to jurisdictional claims in published maps and institutional affiliations.

\section{Author details}

${ }^{1}$ Smithsonian Tropical Research Institute, PO Box 0843-03092, Panama, Republic of Panama. ${ }^{2}$ Universidad San Francisco de Quito, Diego de Robles $\mathrm{s} / \mathrm{n}$, Quito, Ecuador. ${ }^{3}$ Biology and Natural Resources Department, Principia College, Elsah, IL 62028, USA.

Received: 7 December 2017 Accepted: 11 April 2018

Published online: 19 April 2018

\section{References}

Argos CLS. Argos user manual worldwide tracking and environmental monitoring by satellite. Ramonville Saint-Anne: CLS Service Argos; 2011.

Block BA, Dewar H, Blackwell SB, Willians TD, Prince ED, Farwell C, Boustany A, Teo SLH, Seitz A, Walli A, Fudge D. Migratory ovements, depth preferences, and thermal biology of Atlantic Bluefin tuna. Science. 2001;293:1310-4.

Block BA, Jonsen ID, Jorgensen SJ, Winship AJ, Shaffer SA, Bograd SJ, Hazen EL, Foley DG, Breed GA, Harrison AL, Ganong JE. Tracking apex marine predator movements in a dynamic ocean. Nature. 2011;475:86-90.

Bonfil R, Meÿer M, Scholl MC, Johnson R, O'Brien S, Oosthuizen H, Swanson S, Kotze D, Paterson M. Transoceanic migration, spatial dynamics, and population linkages of white sharks. Science. 2005;310:100-3.

Castro ALF, Stewart BS, Wilson SG, Hueter RE, Meekan MG, Motta PJ, Karl SA. Population genetic structure of Earth's largest fish, the whale shark (Rhincodon typus). Mol Ecol. 2007;16:5183-92.

Costa DP, Robinson PW, Arnould JP, Harrison AL, Simmons SE, Hassrick JL, Crocker DE. Accuracy of ARGOS locations of pinnipeds at-sea estimated using Fastloc GPS. PLoS One. 2010;5:1-9.

Douglas DC, Weinzierl RC, Davidson S, Kays R, Wikelski M, Bohrer G. Moderating Argos location errors in animal tracking data. Methods Ecol Evol. 2012;3:999-1007.

Eckert SA. High-use areas for Atlantic leatherback sea turtles (Dermochelys coriacea) as identified using satellite telemetered location and dive information. Mar Biol. 2006;149:1247-57.

Eckert SA, Dolar LL, Kooyman GL, Perrin W, Rahman RA. Movements of whale sharks (Rhincodon typus) in south-east Asian waters as determined by satellite telemetry. J Zool (Lond). 2002:257:111-5.

Eckert SA, Stewart BS. Telemetry and satellite tracking of whale sharks, Rhincodon typus, in the sea of Cortez, Mexico, and the North Pacific Ocean. Environ Biol Fish. 2001;60:299-308.

Hearn AR, Green J, Roman MH, Acuña-Marrero D, Espinoza E, Klimley AP. Adult female whale sharks make long-distance movements past Darwin Island (Galapagos, Ecuador) in the eastern tropical Pacific. Mar Biol. 2016; 163:213-24.

Hearn AR, Green JR, Espinoza E, Peñaherrera C, Acuña D, Klimley AP. Simple criteria to determine detachment point of towed satellite tags provide first evidence of return migrations of whale sharks (Rhincodon typus) at the Galapagos Islands, Ecuador. Anim Biotelemetry. 2013;1:1-11.

Hueter RE, Tyminski JP, de la Parra R. Horizontal movements, migration patterns, and population structure of whale sharks in the Gulf of Mexico and northwestern Caribbean Sea. PLoS One. 2013;8:1-19.

Kim YY, Qu T, Jensen T, Miyama T, Mitsudera H, Kang HW, Ishida A. Seasonal and interannual variations of the north equatorial current bifurcation in a highresolution OGCM. J Geophys Res-Oceans. 2004;109:1-19.

Luschi P. Long-distance animal migrations in the oceanic environment: orientation and navigation correlates. ISRN Zoology. 2013;2013:1-23.

Poloczanska ES, Brown CJ, Sydeman WJ, Kiessling W, Schoeman DS, Moore PJ, Brander K, Bruno JF, Buckley LB, Burrows MT, Duarte CM. Global imprint of climate change on marine life. Nat Clim Chang. 2013;3:919.

Qiu B, Rudnick DL, Cerovecki I, Cornuelle BD, Chen S, Schönau MC, McClean JL, Gopalakrishnan G. The Pacific north equatorial current: new insights from the origins of the Kuroshio and Mindanao currents (OKMC) project. Oceanography. 2015;28:24-33.

Robinson RA, Crick HQ, Learmonth JA, Maclean I, Thomas CD, Bairlein F, Forchhammer MC, Francis CM, Gill JA, Godley BJ, Harwood J. Travelling through a warming world: climate change and migratory species. Endanger Species Res. 2009;7:87-99.

Rosenbaum HC, Maxwell SM, Kershaw F, Mate B. Long-range movement of humpback whales and their overlap with anthropogenic activity in the South Atlantic Ocean. Conserv Biol. 2014;28:604-15.

Ryan JP, Green JR, Espinoza E, Hearn AR. Association of whale sharks (Rhincodon typus) with thermo-biological frontal systems of the eastern tropical Pacific. PLoS One. 2017;12(8):e0182599. 
Schick RS, Roberts JJ, Eckert SA, Halpin PN, Bailey H, Chai F, Shi L, Clark JS. Pelagic movements of Pacific leatherback turtles (Dermochelys coriacea) highlight the role of prey and ocean currents. Mov Ecol. 2013;1:1-14.

Schmidt JV, Schmidt CL, Ozer F, Ernst RE, Feldheim KA, Ashley MV, Levine M. Low genetic differentiation across three major ocean populations of the whale shark, Rhincodon typus. PLoS One. 2009;4:1-9.

Sequeira AM, Mellin C, Fordham DA, Meekan MG, Bradshaw CJ. Predicting current and future global distributions of whale sharks. Glob Change Biol. 2014;20:778-89.

Sequeira AMM, Mellin C, Meekan MG, Sims DW, Bradshaw CJA. Inferred global connectivity of whale shark Rhincodon typus populations. J Fish Biol. 2013;82:367-89.

Sleeman JC, Meekan MG, Wilson SG, Polovina JJ, Stevens JD, Boggs GS, Bradshaw CJA. To go or not to go with the flow: environmental influences on whale shark movement patterns. J Exp Mar Biol Ecol. 2010:390:84-98.

Toole JM, Millard RC, Wang Z, Pu S. Observations of the Pacific north equatorial current bifurcation at the Philippine coast. J Phys Oceanogr. 1990;20:307-18

Tougaard J, Teilmann J, Tougaard S. Harbour seal spatial distribution estimated from Argos satellite telemetry: overcoming positioning errors. Endang Species Res. 2008:4:113-22.

Vignaud TM, Maynard JA, Leblois R, Meekan MG, Vázquez-Juárez R, RamirezMacias D, Pierce SJ, Rowat D, Berumen ML, Beeravolu C, Baksay S, Planes S. Genetic structure of populations of whale sharks among ocean basins and evidence for their historic rise and recent decline. Mol Ecol. 2014;23:2590-601.

Weng KC, Castilho PC, Morrissette JM, Landeira-Fernandez AM, Holts DB, Schallert RJ, Block BA. Satellite tagging and cardiac physiology reveal niche expansion in salmon sharks. Science. 2005;310:104-6.

Wilson SG, Polovina JJ, Stewart BS, Meekan MG. Movements of whale sharks (Rhincodon typus) tagged at Ningaloo reef, Western Australia. Mar Biol. 2006; 148:1157-66.

Wyrtki K. Circulation and water masses in the eastern equatorial Pacific Ocean. Int J Oceanol Limnol. 1967;1:117-47.

Wyrtki K. Equatorial currents in the Pacific 1950 to 1970 and their relations to the trade winds. J Phys Oceanogr. 1974;4:372-80.

Ready to submit your research? Choose BMC and benefit from:

- fast, convenient online submission

- thorough peer review by experienced researchers in your field

- rapid publication on acceptance

- support for research data, including large and complex data types

- gold Open Access which fosters wider collaboration and increased citations

- maximum visibility for your research: over $100 \mathrm{M}$ website views per year

At BMC, research is always in progress.

Learn more biomedcentral.com/submissions 